\title{
Fishing for Leviathans? Shifting Views on the Liberal State and Development in Peruvian History
}

\author{
PAUL GOOTENBERG*
}

Abstract. This essay examines the shifting conceptions of the state and development through recent waves of Peruvian historiography. The broad structuralist-dependency interpretations of the I970s and I 980 s gave way to a more diffuse and creative 'political turn' during and after the I990s. These changing historical ideas, which still defy synthesis, relate to distinctive global conceptions and phases of economic liberalism, the changing perceived role of states in development, and the integration and social disciplining of a vastly unequal Peruvian nation. Aspects of these Peruvian historical debates may help to shed light on similar controversies through much of the region.

Keywords: Peru, historiography, nineteenth century, liberalism, development, the state

This essay, part think-piece, part historiography, is an attempt to untangle changing perspectives on the tensions between liberalism and economic development in nineteenth-century Latin America. I use the nation I know best, Peru, as an empirical life jacket to stop myself from drowning in too many distinctions and details. Since the i960s, larger social science, political and policy controversies about liberalism, the state and possibilities for economic growth have shifted ground repeatedly, as have their related historical debates. In the I970s, structuralist and dependency perspectives deeply informed the questions posed by historians and social scientists about markets,

Paul Gootenberg is a professor of history and sociology at Stony Brook University, New York. Email: paul.gootenberg@stonybrook.edu.

* This essay was originally drafted for the symposium, 'Paper Leviathans: State-Building in Latin America and Spain', held at Princeton in 2009. It evolved with Miguel Centeno's guidance and the input of later $J L A S$ reviewers. I especially thank Paulo Drinot for his publication idea, and Alan Knight for comments both at Princeton and at the analogous workshop on 'Economic Liberalism in the Americas', held at the Institute for the Study of the Americas of the University of London in 2012. 


\section{Paul Gootenberg}

state-building and Latin American development. ${ }^{I}$ In the decades that followed, disenchanted by the twin crises of developmentalism and kindred paradigms of history during the I980s, many historians turned away from 'big questions' of economic history and towards more political and micro facets of liberalism and the state. Historians must still reconcile these successive 'developmental' and 'political' turns in studies of the Latin American state, and this commentary is meant to foster positively such cross-disciplinary discussion.

To provide some context, historians had become fascinated with Peru by the I 970 os because it seemed to present one of the region's most flagrant cases of 'failed' national development, unlike the case of Mexico, which at the time still appeared more successful over the long term. This comparison seems ironic now as Peru has registered a straight decade of solid economic growth, with credible political stability, while Mexico has fallen behind economically since the early 1980 s and, with its drug-related violence and graft, is often labelled by pundits as a looming 'failed state'. Nineteenth-century Peru was the scene both of spectacular economic opportunities - the guano and nitrate export bonanzas - and of a frenetic spurt of state-building under the rubric of modernising free-trade liberalism. Yet neither phenomenon led to appreciable or sustained development or even, it seems, a genuine and integrated new nation. Indeed, at the end of the century, in the I $890 \mathrm{os}$, the country was just as lagging and 'colonial', with its stark ethnic divides and oppressions, as it had been in the waning viceregal era. One could say that Peru 'declined' under nineteenth-century liberalism. This unfortunate post-colonial saga made Peru one of the darlings of I 970 dependency historians (and then scholars making more nuanced critiques of liberal modernisation recipes), in ways that echoed, if more loudly, the discontent of similar revisionists throughout the Americas. I leave it to readers to decide whether its extremity makes Peru an apt empirical case for generating larger insights about the broader historiography of economic liberalism in Latin America. I think it may, insofar as Peru's historical reality gaps (cultural and material divides between rural Indian peasants and dominating westernised urban elites; between differently constructed regionalisms like coast, sierra and selva; between universal liberal doctrines and the restricted practice of Peruvian citizenship and the state; and between articulated aspirations to modern economic progress and failures to achieve them) put into relief many of the issues and intellectual trends found almost everywhere about the newly founded nation-states of Latin America.

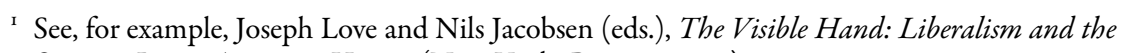
State in Latin American History (New York: Praeger, 1988). 


\section{The Developmental Turn (1960s-1980s)}

Developmentalist historical interpretations, needless to say, leaned heavily on implicit recipes (or prescriptive teleologies) as to what the new national states and elites of Peru or Latin America should have done in the decades following independence. These ideas, such as building more diverse national economies or even joining the industrial revolution, reflected the robust sense of what 'had to be done' inherited from i 960 s-style economic developmentalism, before the doubts sown by radical critiques of it in the I 970 and the rapid rise of neoliberalism in the $1980 \mathrm{os}$. But these formulas also departed from quite disparate sociological idealisations or 'counterfactuals' of modernising states, or from vastly different notions about the working relationships of states to liberal markets. However mired in economic determinism these models were, the questions they posed often sparked wonderful historical research.

To simplify these developmental interpretations, I group them here into three main ways in which historians depicted Peru's stunted Leviathan in the century after independence.

First, some historians argued that republican elites were incapable of mounting real or thoroughgoing liberal-capitalist national projects. A true national 'bourgeoisie' was puny and weak and, lacking a base in internal markets or in alliances with other internal social groups, devolved into appendages of foreign merchants and powers ('compradors') with no stake in internal transformation. Lacking the capacity for civil politics in the state, urban elites also became political lackeys of militaristic caudillos or rustic gamonales, the antitheses of modern liberalising agents. As the Peruvian state became bloated with export bounties after I 850 , few resources went into the transformation of capitalist markets or the legal system; instead, much was wasted on Pharaonic export-promotion projects like Andean railways or giveaways to rentier 'crony capitalist' cliques, both national and foreign. ${ }^{2}$ Eighteenth-century (Smithean) economic and constitutional liberalism was never tried, nor ever had a chance, in remote outposts of the post-colonial 'West' like Peru.

The second opposite interpretation was that post-independence elites and states proved incapable of leading an anti-liberal, statist or national transformation of their countries along the lines of Bismarckian Germany or Meiji Japan. States like Peru's would not have embarked on socialism or autarchy, but historians have suggested some kind of nationalist, locally

${ }^{2}$ See Heraclio Bonilla, Guano y burguesía en el Perú (Lima: Instituto de Estudios Peruanos, 1974); and Un siglo a la deriva: ensayos sobre Perú, Bolivia y la guerra (Lima: Instituto de Estudios Peruanos, 1980); and Ernesto Yepes de Castillo, Perú 1820-1920: un siglo de desarrollo capitalista (Lima: Instituto de Estudios Peruanos, 1972). These are but a few exemplary citations for these trends in the r 970 s. 


\section{I24 Paul Gootenberg}

defined, strong state or industrial nineteenth-century 'Gerschenkronian' reaction to the region's lag behind the post-eighteenth-century liberal transformations of northern European and North American states. ${ }^{3}$ Peru's state would have had to have been coherent and integrative, which it was not, and its elites, beguiled by alien forms of liberalism (possessive individualism, private property rights or consumption of imported fashions), would have had to embrace a starker and more assertive vision of their historic leading role.

Third, rather than finding fault with either liberal or $i$ liberal nationalism, there was a more hybrid stream of analysis. Post-colonial elites and nascent European-style states in places like the Andes were embedded in societies that were simply too fragmented, regionally and ethnically divided or socially heterogeneous to produce anything as clear as the two historical options sketched above. In mixed fashion, much of the country was mired in its 'precapitalist' relationships and mentalities. Its elites were neither proto-capitalist liberals like early Argentine patriots nor conservatively 'feudal' like Brazil's slavocracy, having inherited social elements haphazardly from Hapsburg and Bourbon colonial institutions and political cultures. A transformative strong state of any kind was extremely unlikely in the Andes. ${ }^{4}$ Here, the angle was more analytical than prescriptive, but still obsessed with a state that failed to appear.

Clearly, the main tension in these past state-seeking interpretations was between historical social scientists who deemed that countries like Peru had never experienced a true, deep, unfettered 'liberalism', and those who deemed that liberalism in a 'post-colonial' setting (to tap the later terminology) had penetrated Peru but was simply a wrong, misguided or inauthentic path to sustained national development. These sociological lenses became complemented, complicated and sometimes contested by an emerging ethnographic, engaged, 'bottom-up' national school of social history, which came to be known as la nueva historia (the New History), pioneered by scholars like Alberto Flores Galindo, Manuel Burga and Nelson Manrique, who began publishing later in the I 970 . 5 For developmentalists, politics or active political

3 Javier Tantaleán, Politíca económico-financiera y la formación del estado: siglo XIX (Lima: Pontificia Universidad Católica del Perú, 1983); see also Paul Gootenberg, 'Hijos of Dr. Gerschenkron: 'Latecomer' Conceptions in Latin American Economic History', in Miguel Angel Centeno and Fernando Lopez-Alves (eds.), The Other Mirror: Grand Theory through the Lens of Latin America (Princeton, NJ: Princeton University Press, 200I), pp. $55-80$.

4 Julio Cotler, Clases, estado y nación en el Perú (Lima: Instituto de Estudios Peruanos, I 978); Paul Gootenberg, Between Silver and Guano: Commercial Policy and the State in Postindependence Peru (Princeton, NJ: Princeton University Press, 1989).

5 On that older 'New History', see Heraclio Bonilla, 'The New Profile of Peruvian History', Latin American Research Review, 16: 3 (1981), pp. 210-24; and Paulo Drinot, 'Historiography, Historiographic Identity and Historical Consciousness in Peru', Estudios 
transformation were not at issue: no truly 'serious' civil parties or visions, it was thought, existed among elites; majoritarian but disarticulated peasants in the faraway sierra remained mostly out of the picture (or else the backward, utopian or patriotic rebels were betrayed by self-serving coastal ruling cliques); and the small urban labouring masses on the coast remained in 'pre-political' or racially oppressed dependence. ${ }^{6}$ Needless to say, neither of these historical visions of liberalism was closely based on empirical research. Provoked by these dubious grand conceptions, however, the work that followed would make the real historical choices faced by Peru more nuanced, and perhaps less historically demanding.

\section{The Political Turn (Iggos Onward)}

Since the I 980 , younger historians have generally turned away from the grand 'teleologies' and the confident 'economic determinism' dissected above. This is not a turn from history: more and better historical research is being done today in Peru and about nineteenth-century Latin America than ever before. The best recent analyst of the larger trends, Paulo Drinot, sees a discernible shift in the political 'locus' of Peru's historical production, battered by the crises of academic institutions and employment that occurred in the r 980 s and I 9905. 7 The results do not necessarily reflect the 'cultural' or 'subaltern' turn promoted by many North American specialists, though more cultural, social and ethnic influences have filtered into political historical analysis. What we see is thus largely a turn to 'politics' or 'political culture', to use Nils Jacobsen's revived term, in understandings of the Peruvian and Latin American state.

Interdisciplinarios de América Latina y el Caribe, I 5: I (2005), pp. 65-88. Canonical works of this school include Manuel Burga and Alberto Flores Galindo, Apogeo y crisis de la República Aristócratica: oligarquia, aprismo, y comunismo en el Perú, 1895-1932 (Lima: Rikchay Perú, 1979); Alberto Flores Galindo, Aristocracia y plebe: Lima, 1760-1830. Estructura de clases y sociedad colonial (Lima: Mosca Azul, I984); Manuel Burga, De la encomienda a la hacienda capitalista: el Valle de Jequetepeque del siglo XVI al XIX (Lima: Instituto de Estudios Peruanos, 1976); and Nelson Manrique, Las guerrillas indigenas en la guerra con Chile: campesinado y nación (Lima: Centro de Investigación y Capacitación, I981). It remains difficult to fit the heterodox and influential historian Pablo Macera into such genealogies: see his Trabajos de historia, 4 vols. (Lima: Instituto Nacional de Cultura, 1977).

${ }^{6}$ Florencia E. Mallon, The Defense of Community in Peru's Central Highlands: Peasant Struggle and Capitalist Transition (Princeton, NJ: Princeton University Press, 1983); Margarita Giesecke, Masas urbanas y rebelión en la historia: golpe de estado, Lima, 1872 (Lima: Centro de Divulgación de Historia Popular, 1978).

7 Drinot, 'Historiography, Historiographic Identity and Historical Consciousness'; Nils Jacobsen and Cristóbal Aljovín de Losada (eds.), Political Cultures in the Andes, 1750-1950 (Durham, NC, and London: Duke University Press, 2005); Brooke Larson, Trials of Nation Making: Liberalism, Race, and Ethnicity in the Andes, 1810-19Io (Durham, NC, and London: Duke University Press, 2004). 


\section{I26 Paul Gootenberg}

Going beyond the exhausted developmental policy paradigm of the 1960s and I970s, this turn reflected the positive search for the historical roots of 'civil society' or 'citizenship', broadly defined, during the sometimes literally tortured late twentieth-century process of national re-democratisation. It also emerged during a period when a strong universal prescription for liberalism of all kinds (economic 'neoliberalism', post- 989 global democratic triumphalism) made historians reassess the first long regional encounters with the comparable modernity and modernisation projects of the nineteenth century. In Peru, perhaps more than in other authoritarian contexts, this quest for a different (kinder? gentler?) Leviathan intensified during the distressing struggle between the terrorism of Sendero Luminoso and the corresponding state terrorism, and the resulting degradation of human rights generally, which occurred in the I 980 os. The country seemed to lack any effective buffer or alternative in elite civic or inclusionary popular politics. The core question for intellectuals became: why was liberal democracy so historically incapable, weak or 'underdeveloped' in places like Peru?

It is best to arrange the contributions of the political turn by trends and themes rather than implicit models, because of its continuing timidity with regard to modelling or even broader historical synthesis. The reading that follows is by no means an exhaustive or formal historiographical analysis of these trends, or one that is attentive to all the new and key research. Often, the biggest historical questions have been posed in negative terms, relative to older Marxist-inflected structural and social history: as history beyond 'domination' and 'resistance' or as a tension between 'Gramscian' and 'Tocquevillian' political optics (interpreted as top-down hegemonic versus bottom-up agency perspectives). ${ }^{8}$ These research interests remain diverse, even disparate, although in generational and intellectual terms this group has succeeded the socially inflected New History of the I970s, which itself had just superseded Peru's long hegemonic oligarchic and liberal historiography.

One stream of work debates the possibilities, organisation and political meaning of the nascent political press, clubs and parties, especially Manuel Pardo's anti-militarist Partido Civil of the 1870 s, or the reconstructive elite political movement of Nicolás de Piérola and recuperating civil elites following the War of the Pacific (1879-83). There are a number of valuable new works on the performance, rituals, ideologies and reality of 'elections' across early national Peru. Military politics is also a newly central topic. 9 The social,

${ }^{8}$ Paulo Drinot and Leo Garofalo (eds.), Más allá de la dominación y la persistencia: estudios de historia peruana, siglos XIX-XX (Lima: Instituto de Estudios Peruanos, 2005); Drinot, 'Historiography, Historiographic Identity and Historical Consciousness'; Jacobsen and Aljovín (eds.), Political Cultures in the Andes.

9 Cristóbal Aljovín, Caudillos y constituciones: Perú, I82I-1845 (Lima: Pontificia Universidad Católica del Perú, 2000); Cristóbal Aljovín and Sinesio López, Historia de las elecciones en el 
political and regional bases of caudillo mobilisation - in early republican Cusco, for example-have gained far more study, as have extra-regional political projects such as the striking Peru-Bolivia Confederation of the 1830 , and the unstable constitutionalism and legalism of Peru's tempestuous early regimes.

A more nuanced and rounded vision of peasant participation in politics, beyond the simpler 'nationalist/not-nationalist' or 'resistance/accommodation' binaries of the I980s, is also emerging, ranging in type from the deceivingly 'royalist' or liberal campesinos of Ayacucho to the rural social bandits of Cajamarca to the loyal and tax-paying republicano peasants of Ancash and Cusco. Regional political culture, in reaction to former 'Limacentric' habits and assumptions, has received greater due, whether the 'whiter' honour-based citizenry ideals in early republican Arequipa or the indigenousinflected and charismatically led regional politics of Cusco. ${ }^{10}$ The 'liberalism of the bedroom' and women's claims on the family and political spheres are now out in the open, as is the social impact of turn-of-the-century civilising hygiene campaigns against women (and 'diseased' populations generally), breaking down the traditional barriers between private behaviour and public spheres. There is work on nineteenth-century campesina women and their conflictual encounters with both men and republican law. The gendered politics of Lima's notorious maricones (gays) is studied in shaping manly new republican citizenship ideals. ${ }^{\text {I }}$ The racial and abolitionist politics of coastal blacks during and after independence is finally recognised, together with early

Perú: estudios sobre el gobierno representativo (Lima: Instituto de Estudios Peruanos, 2005); Ulrich Muecke, Political Culture in Nineteenth-Century Peru: The Rise of the Partido Civil (Pittsburgh, PA: University of Pittsburgh Press, 2004); Natalia Sobrevilla, The Caudillo of the Andes: Andrés de Santa Cruz (Cambridge: Cambridge University Press, 20 I I). See also the work of Carmen McEvoy cited in note 22, below.

${ }^{\circ}$ Cecilia Méndez, The Plebeian Republic: The Huanta Rebellion and the Making of the Peruvian State, I820-I850 (Durham, NC, and London: Duke University Press, 2005); Mark Thurner, From Two Republics to One Divided: Contradictions of Postcolonial Nationmaking in Andean Peru (Durham, NC, and London: Duke University Press, 1997); Sarah C. Chambers, From Subjects to Citizens: Honor, Gender, and Politics in Arequipa, Peru, 1784-1854 (Durham, NC, and London: Duke University Press, 1999); Víctor Peralta, En pos de tributo: burocracia estatal, elite regional, y comunidades indigenas en el Cusco rural, i $826-$ I854 (Cusco: Centro Bartolomé de las Casas, 1991); Charles F. Walker, Smoldering Ashes: Cuzco and the Creation of Republican Peru (Durham, NC, and London: Duke University Press, 1999); Luis Miguel Glave, La república instalada: formación nacional y prensa en el Cuzco, $1825-1839$ (Lima: Instituto Francés de Estudios Andinos and Instituto de Estudios Peruanos, 2004).

${ }^{11}$ Christine Hunefeldt, Liberalism in the Bedroom: Quarreling Spouses in Nineteenth-Century Lima (University Park, PA: Penn State University Press, 2000); Tanja Christiansen, Disobedience, Slander, Seduction, and Assault: Men and Women in Cajamarca, Peru, 1862-19oo (Austin, TX: University of Texas Press, 2005); María Emma Mannarelli, Limpias y modernas: género, higiene y cultura en el Lima del novocientos (Lima: Centro Flora Tristán, 1999); Magally Alegre Henderson, 'Androginopolis: Dissident Masculinities and the 
aspects of the black contribution to popular and creole culture, such as Lima's watery Carnival. The search for popular politics and political identities deepens in many guises. The century-long process of defining and redefining republican Peru's 'Indian problem' (and creole mestizaje) is now read as a complex political and representational problematic. There was a longer 'visual politics' of race, shaped by shifting transnational 'contact zones', which helped to congeal republicanised racial and political hierarchies. Racism has become a usable category of historical analysis. ${ }^{\text {I2 }}$

A major new political theme with regard to Peru is civic 'associationism': that is, the question of whether the surprising array of new voluntary, neighbourhood and regional organisations established after independence added to the democratic 'public sphere' of Peru, were politically hollow or left a reasserted 'civilising' order in their wake. Specific urban social groups such as immigrants and artisans, mobilised in electoral campaigns and political struggles over trade, are now fully visible as potential citizens, as are specialised circles of white elites such as physicians and health officials. ${ }^{13}$ Some progress has been made in identifying actual patterns of Lima elite formation and its relationships to state formation. ${ }^{14}$ Involuntary organisations - social control exercised through new-style prisons and punishments - and the coercive definition of law generally are striking novel political chords, as are the unruly criminals, bandits and vagabonds who made them seem so necessary. ${ }^{\text {Is }}$ Lima's changing political space has also won perceptive analysis in terms of how residential patterns, urban renewal campaigns and nationalist

Creation of Republican Peru (Lima, 1790-1850)', unpubl. PhD diss., Stony Brook University, $20 \mathrm{I} 2$.

${ }^{12}$ Deborah Poole, Vision, Race, and Modernity: A Visual Economy of the Andean Image World (Princeton, NJ: Princeton University Press, 1997); Efraín Kristal, Una visión urbana de los Andes (Lima: Instituto de Apoyo Agrario, 1991); Rolando Rojas y Rojas, Tiempos de Carnaval: el ascenso de lo popular a la cultura nacional (Lima, I822-1922) (Lima: Instituto Francés de Estudios Andinos and Instituto de Estudios Peruanos, 2005); Carlos Aguirre, Agentes de su propia libertad: los esclavos de Lima y la desintegración de la esclavitud (Lima: Pontificia Universidad Católica del Perú, 1993); Peter Blanchard, Slavery and Abolition in Early Republican Peru (Wilmington, DE: Scholarly Resources, 1992).

${ }^{13}$ See Iñigo García-Bryce, Crafting the Republic: Lima's Artisans and Nation-Building in Peru, 182I-I 879 (Albuquerque, NM: University of New Mexico Press, 2004); an expanded version is available as República con ciudadanos: los artesanos de Lima, I821-1879 (Lima: Instituto de Estudios Peruanos, 2008).

${ }^{14}$ See Alfonso W. Quiroz, La deuda defraudada: consolidación de I850 y dominio económico en el Perú (Lima: Instituto Nacional de Cultura, 1987); and Banqueros en conflicto: estructura financiera y economia peruana, 1884-1930 (Lima: Centro de Investigación, Universidad del Pacífico, 1989).

is See Carlos Aguirre, The Criminals of Lima and Their Worlds (Durham, NC, and London: Duke University Press, 2005); and Carlos Aguirre and Charles Walker (eds.), Bandoleros, abideos y montoneros: criminalidad y violencia en el Perú. Siglos XVIII-XX (Lima: Instituto de Apoyo Agrario, 1990). 
monument-building modernised and structured the capital's domination and social integration. Recently, 'corruption' has become an overt historical topic for what it reveals about Peru's shifting business of politics, competitive ruling cliques and their relation to the state, and the legitimacy and strength of legal and market institutions. ${ }^{16}$ Previously ignored political ideas are now very respectable: 'developmental' ideas, legal and constitutional debates, medical and technological ideas, political projects, political thinkers (Peru's many forgotten Juan Espinozas) and indigenista visionaries, sometimes critically read as elitist managerial or reactive 'discourses'. In the intellectual history field, there is a growing and informed debate about early Peruvian historians, anthropologists and 'historiographies': how did they rewrite or erase whole peoples and fractured pasts from the republican political imaginary and Peruvian past, or alternatively, give way to non-official memories of the Peruvian 'nationstate'? ${ }^{17}$

One virtue of this sharp political turn, besides its broad and deep stream of excellent new historical work, is that rather than a 'should have done or been' mentality, historians are more attuned to finding out what a real Latin American state was made of politically, or what it 'could' have done. They no longer assume Peruvian history to be one big, continual, jodido (screwed-up) 'failure', or to use Mark Thurner's temporal post-colonial studies terms, as a 'not yet' nation or form of modernity. Rather, they look at politics as they really were, instead of searching for a mythical counterfactual Leviathan. Historians are busily discovering the social bases of politics and thus of more tangible 'possibilisms', to tap Albert O. Hirschman's concept, an idea that had an early national formulation in the I930s with Jorge Basadre's classic ambivalent, alliterative puzzle in the title of his influential book, Perú: problema y posibilidad. To be sure, this sense of open political or cultural possibility is often undercut by r 990s-style Foucauldian fatalism about the inevitability of social ordering and control, though this is more drastically

${ }^{16}$ Natalia Majluf, Escultura y espacio público: Lima, I850-1879 (Lima: Instituto de Estudios Peruanos, I994); Martín Monsalve, 'Civilising Society and the Public Sphere in Multiethnic Societies: Struggles over Citizenship in Lima, Peru, i 850-1 880', unpubl. PhD diss., Stony Brook University, 2005; Alfonso W. Quiroz, Circles of Corruption: A History of Unbound Graft in Peru (Baltimore, MD: Johns Hopkins University Press, 2008).

${ }^{17}$ Paul Gootenberg, Imagining Development: Economic Ideas in Peru's 'Fictitious Prosperity' of Guano, 1840-1889 (Berkeley, CA: University of California Press, 1993); Fernando de Trazegnies, La idea de derecho en el Perú republicano del siglo XIX (Lima: Pontificia Universidad Católica del Perú, 1980); Marcos Cueto, Jorge Lossío and Carol Pasco (eds.), El rostro de la salud pública en el Perú (Instituto de Estudios Peruanos and Universidad Cayetano Heredia, 2009); Paul Gootenberg, La invención de la cocaina: la historia olvidada de Alfredo Bignon y la ciencia nacional peruana (1 884-1 890) (Lima: Instituto de Estudios Peruanos, 2010); Joseph Dager Alva, Historiografía y nación en el Perú del siglo XIX (Lima: Pontificia Universidad Católica del Perú, 2009); Mark Thurner, History's Peru: The Poetics of Colonial and Postcolonial Historiography (Gainesville, FL: University Press of Florida, 20 I I). 
embraced outside Peru's national historiography. ${ }^{18}$ This latter trend is being tempered by historians' rediscovery of Norbert Elias' sociological notion of internalised and assimilated 'civilising habits' ('habitus' in the customary terminology) in the long-term consolidation of political cultures and regimes. And since nearly all of this work is divorced from questions of economic, fiscal, state or capitalist development, a lonely exception being the dedicated and wide-ranging economic historian Carlos Contreras, or the impact of larger material constraints and structured inequalities on citizenship and politics, it also suffers a utopian streak. ${ }^{19}$ This untethered 'agency' erupts strikingly in exaggerated portrayals of the impact of sundry political actors, from remote peasant rebels to outcast thinkers to corrupted-to-the-core urban politicians and elites. Unlike the grand interpreters of the I970s, who interpreted first and investigated later, these smaller-scale political findings have yet to congeal into any larger new visions or syntheses about an Andean Leviathan - that is, whether any large or strong or predatory state has ever surfaced in the Andes.

As a non-member of this historical cohort, it is hardly my place (nor really in my capacity) to make this synthesis. ${ }^{20}$ However, a number of generalities (and perhaps generalities to other Latin American contexts) can be made about these writings, about the tensions within them and with the developmentalist turn of the past. One comparison is obvious: while previously the success of the state and state-building was on trial, by the I 990 s it was the existence of a viable 'nation' (as an Andersonian political and cultural community) and popular and cultural citizenship that counted. The relationship of the state or

${ }^{18}$ Jorge Basadre, Peru: problema y posibilidad. Ensayo de una sintesis de la evolución histórica del Perú (Lima: F. y E. Rosay, I93 I); Mark Thurner, 'After Spanish Rule: Writing Another After', in Mark Thurner and Andrés Guerrero (eds.), After Spanish Rule: Postcolonial Predicaments of the Americas (Durham, NC, and London: Duke University Press, 2003), pp. I 2-57; Albert O. Hirschman, A Bias for Hope: Essays on Development and Latin America (New Haven, CT: Yale University Press, 197I).

19 Carlos Contreras, El aprendizaje del capitalismo: estudios de historia económica y social en el Perú (Lima: Instituto de Estudios Peruanos, 2004); Carlos Contreras and Manuel Glave (eds.), Mercado y estado en la historia del Perú (Lima: Pontificia Universidad Católica del Perú, 2002); see also Contreras' recent La economía pública en el Perú despues del guano y del salitre: crisis fiscal y élites económicas durante su primer siglo independiente (Lima: Instituto de Estudios Peruanos and Banco Central de Reserva del Perú, 20 I 2).

20 There are, however, textbooks in Peru that build upon the latest wave of historical research, a good example being Marcos Cueto and Carlos Contreras, Historia del Perú contemporáneo (Lima: Pontificia Universidad Católica del Perú, 2004). A larger synthesis, Carlos Forment, Democracy in Latin America, I760-19oo: Civic Selfhood and Public Life in Mexico and Peru (Chicago, IL: University of Chicago Press, 2003), offers ambitious comparisons of nineteenth-century political cultures. However, despite a new evidence base, it puts forward the dismal reading of Peru as the failed foil case to Mexico's rising nineteenth-century associative democracy. This is the same facile dichotomising strategy adopted by most PeruMexico comparisons - for example, the incorporative liberal 'nationalism' put forth by Florencia E. Mallon, Peasant and Nation: The Making of Postcolonial Mexico and Peru (Berkeley, CA: University of California Press, 1995). 
republicanism to these nationality and identity concerns is just beginning to be untangled. Another keynote in Latin American historiography (or universally since around 1989) is the widespread, often culturalist 'postmodern' scepticism of 'modernisation' or 'modernity' projects writ large, rather than any specific kind of imported, liberal or non-liberal path of modernisation. Through the now hoary filter of Foucault, modernity and 'the' state were read primarily as limiting rather than liberationist in terms of human possibilities, and in the extreme, all modernist concerns with material 'development' or conditions of 'poverty' as strictly oppressive. ${ }^{21}$ This broad critique of Western modernity that none of it really works or fits - can lead historians and others into some pretty obscure, micro or particular corners, or into a desperate search for an authentic indigenous 'alternative' modernity, one that rivals or mimics the pyrrhic New Left search for alternative states, development or class consciousness of the I970s and I980s. This is practically a universal trend of scepticism in 'southern' historiographies since 1989 . In this turn, there is a good deal of slippage between liberalism and 'modernity' - liberalism is at once illiberal and a stand-in for authoritarian rationalism - and a deep ambivalence about the necessity of state hegemony, cohesion or control. This is not to mention related questions of historical scale: macro versus micro politics, public versus private spheres, subjectivised agency versus the externalised identity cage of social class. In the main, the fragmentation of historiography (whether from a weak synthetic will or the theoretical allure of discursive, nonstate or intimate capillary power) has not led to a holistic re-evaluation of the role of larger national ideologies and 'projects' such as nineteenth-century liberalism. ${ }^{22}$

\section{Rethinking the Unintegrated Nation and Unequal Development?}

One set of integrative issues, which might be addressed more rigorously in long-run research, concerns the connection and overlaps between political legitimacy and the 'social disciplining' power of nascent nineteenth-century states like Peru's. During the recent Foucauldian wave it was assumed (quite

${ }^{21}$ See Arturo Escobar, Encountering Development: The Making and Unmaking of the Third World (Princeton, NJ: Princeton University Press, 1995); and, generally, Dipesh Chakrabartry, Provincialising Europe: Postcolonial Thought and Historical Difference (Princeton, NJ: Princeton University Press, 2000). Gootenberg, Imagining Development, was not, I hope, part of this anti-development trend.

${ }^{22}$ Carmen McEvoy is the prolific exception, although her rich corpus tends to focus on political rather than economic liberalism: see Carmen McEvoy, Un proyecto nacional en el siglo XIX: Manuel Pardo y su visión del Perú (Lima: Pontificia Universidad Católica del Perú, 1994); La utopía republicana: ideales y realidades en la formación de la cultura política peruana (1871-1919) (Lima: Pontificia Universidad Católica del Perú, 1994); Forjando la nación: ensayos de historia republicana (Lima: Pontificia Universidad Católica del Perú, 1999); and many more over the past decade. 


\section{I32 Paul Gootenberg}

wrongly, I think) that 'the state' actually enjoyed the institutional coherence to deploy disciplinary power, even in the discursive and internalising sense of subject- and/or citizen-making. These forms of 'governmentality', as Drinot adroitly shows for even twentieth-century Peru, remained limited to strategic urban and formal sectors of the state. ${ }^{23}$ This organising or ordering power, or lack thereof, is analogous to earlier general debates around Peru's lack of 'national integration'. For the older developmentalists, of course, there was the equally utopian assumption that the state, had it not been undermined by global imperialists and their local class lackeys, would have had the coherence and strength to mount a Gerschenkronian 'national' project along the lines of nineteenth-century Germany or Japan, which assumes the political focus, capacity or appeal to mobilise en masse the state's claimed citizens and subjects. Many historians, taking a lead from Barrington Moore Jr., might wonder if such historical formulas for accelerated development led to reactionary politics or fascism rather than to a democratised citizenry. Indeed, this is what Latin American sociologists such as Guillermo O'Donnell suggested with the original 'bureaucratic authoritarianism' thesis about the industrial politics of the harshly disciplinary dictatorships of the 1970s, a century later. ${ }^{24}$ This state mobilisation or organisational incapacity was a special challenge in places like nineteenth-century Peru, whereas 'forced savings'-type investment, central to Gerschenkron's classic analysis of catch-up European states, was not the key developmental issue, given the massive public bounties available from Peru's nationally controlled exports like guano and nitrates, and later, the opportunity for overseas finance of public projects. It can be argued that Peru's state lacked national mobilisation powers until its concrete institutional central expansion in the r 920 s under an increasingly authoritarian president, Augusto B. Leguía, and arguably Peru's most potent effort ever at reshaping its own citizenry and development, during the illiberal military regime of President Velasco between 1968 and 1975 - a full century after the state's formative era - still lacked the governmental power to succeed.

${ }^{23}$ Paulo Drinot, The Allure of Labor: Workers, Race, and the Making of the Peruvian State (Durham, NC, and London: Duke University Press, 20 I I).

${ }^{24}$ On Moore and Latin America (and there should be more), see J. Samuel Valenzuela, 'Class Relations and Democratisation: A Reassessment of Barrington Moore's Model', in Centeno and López-Alves (eds.), The Other Mirror, pp. 240-86; on the O'Donnell thesis, see David Collier (ed.), The New Authoritarianism in Latin America (Princeton, NJ: Princeton University Press, 1979). For Peru's public use of export revenues, see Shane J. Hunt, 'Growth and Guano in Nineteenth-Century Peru', Research Programme in Economic Development Discussion Paper 34 (Princeton NJ: Woodrow Wilson School, Princeton University, 1973). Hunt's important papers on nineteenth-century Peru, most of which were written in the I970s, have now been published together as La formación de la economía peruana: distribución y crecimiento en la historia del Perú y América Latina (Lima: Instituto de Estudios Peruanos and Banco Central de Reserva del Perú, 20 I I). 
If 'social discipline', for better or worse, is taken as a key ingredient of state formation and liberalism, these can be researchable questions, lit by comparative perspectives. There are now wider literatures from which to bounce off: for example, Diane Davis has recently focused on social discipline (and its relative deficits and defects) in Latin America's twentieth-century development endeavours, in comparison with the social disciplinary forces undergirding the gamut of Asian economic 'miracles' between the I970s and the I 990 s, most of which, likely not by coincidence, occurred in far more socially egalitarian and middle-class-enlarging societies than Latin America's. ${ }^{25} \mathrm{~A}$ number of European historians and historical sociologists are also critically re-examining the classic Weberian thesis linking discipline to religion, individualism, the growing powers of the early modern state, and the early modern birth of capitalism itself. In contrast to the modernist idea of the external autonomous or Weberian coercive power of the state, which surely became a feature of most of the modern polities of twentieth-century Latin America, enduring power, mobilisation capacities and economic dynamism swell from the culturally inflected, 'internalised' self-disciplining of emergent labouring classes, entrepreneurial groups, the army, civic sphere or citizenry.

Yet in places like the Andes, the initial post-colonial and post-independence era, considered here as the period from i 8 i 5 to i 895 , is best seen as an era of loss of the powers, discipline and legitimacy of the state. Indeed, according to the larger recent socio-historical scheme of James Mahoney, this peripheralised branch of the Spanish colonial state in Lima had long been suffering structural decay, both during and after the Bourbon reforms. Late colonial Lima, as illuminated by Flores Galindo, was also a seething site of social and racialised defiance of customary authority, not necessarily in the recognisable style of subaltern 'resistance'. This was interpreted by Lima elites as a loss of moral bearings and power, and those elites thus resisted independence in conservative rearguard fashion. ${ }^{26}$ After $182 \mathrm{I}$ Peru also constituted a paradigmatic case where the state, however feeble, came first, and 'the nation' and associated citizenry projects were long in following. This is one reason

${ }^{25}$ Diane E. Davis, Discipline and Development: Middle Classes and Prosperity in East Asia and Latin America (Cambridge: Cambridge University Press, 2004); Miguel Centeno, 'The Disciplinary Society in Latin America', in Centeno and López-Alves (eds.), The Other Mirror, pp. 289-308; Philip S. Gorski, The Disciplinary Revolution: Calvinism and the Rise of the State in Early Modern Europe (Chicago, IL: University of Chicago Press, 2003).

${ }^{26}$ See James Mahoney, Colonialism and Postcolonial Development: Spanish America in Comparative Perspective (Cambridge: Cambridge University Press, 2010); and Flores Galindo, Aristocracia y plebe. Since the publication of Flores Galindo's work, there has been much good new research on late colonial Lima: see, for example, Christine Hunefeldt, Las Manuelas: vida cotidiana de una familia negra en la Lima del siglo XIX (Lima: Instituto de Estudios Peruanos, 1992); or Francisco Quiroz Chueca, Artesanos y manufactureros en Lima colonial (Lima: Instituto de Estudios Peruanos, 2008). 


\section{34 Paul Gootenberg}

why Benedict Anderson's striking mid-i 980 os assertion of 'creole patriots' as the inventors of modern Western nationalism (even the specific ones who named this republic 'Peru') seems so awkward to most Latin Americanists, even as we continue to borrow from his pat phrases and culturalist baggage. Claudio Lomnitz's thoughtful retort to Anderson makes better sense: that places like Mexico (and Peru, to return to its frequent direct comparison) were poor in nation-style horizontal and ideational solidarities, but abounded in vertical, top-down, centrifugal, corporate and coerced loyalties. ${ }^{27}$

But Peru, especially during the first three decades after colonialism, and again in the two decades of national-state collapse that followed the War of the Pacific, was basically, I would think, an ungoverned or ungovernable country, where even most vertical ties came undone. It was a 'minnow' of a state rather than a Leviathan. This weakness was both a cause and an effect of its feeble citizenry and nationalist allegiances. Regionalist and caudillo warfare, public penury and debt, deep geographic fragmentation (as roads and commercial routes decayed), social difference, distances and ethnic inequalities, and the breakdown of formal colonial caste hierarchies and institutions meant that the majority of Peru's people were basically on their own. Most Peruvians were not yet articulated to a central or local government through the emotive or identity ties of citizen-making (loyalty, patriotism, nationalism) that culturalists like to talk about, nor subject to institutionalised deference or legal controls through policing, law, prisons, or customary or forced work duties for which retrospective 'state-builders' might have pined. Rather, the strongest loyalties or ties in politics were to ephemeral caudillo figures or factions, which in turn (a few localised exceptions aside) were themselves feebly connected (though they were connected) to national projects such as liberalism or Church-style conservatism. Most Peruvians were likely unnerved by the instability, shifts and unpredictable rounds of violence of the times. They lacked, save for a well-organised corporatist consulado merchant class around Lima, even a rudimentary working Tillyan 'protection racket' warstate. ${ }^{28}$ In the meantime, slavery and other forced labour regimes disintegrated along the coast, a zone hit by fearsome banditry, as did old-style colonial urban disciplining institutions such as guilds, militias and cofradias, only faintly and slowly replaced during the nineteenth century by elite or worker voluntary associations.

${ }^{27}$ Claudio Lomnitz, 'Nationalism as a Practical System: Benedict Anderson's Theory of Nationalism from the Vantage of Spanish America', in Centeno and López-Alves (eds.), The Other Mirror, pp. 329-59.

${ }^{28}$ Charles Tilly, 'War Making and State Making as Organized Crime', in Peter Evans, Dietrich Rueschemeyer and Theda Skocpol (eds.), Bringing the State Back In (Cambridge: Cambridge University Press, 1985), pp. 165-87; Gootenberg, Between Silver and Guano. 
In the vaster sierra, 'Indians' seem to have gained a fair measure of autonomy, whether they wanted it or not, and with or without the ties of colonial-style kuraka state intermediaries. In an essay published two decades ago, I speculated that this disintegration of the colonial order, paradoxically, had a lot to do with the resurgence of majoritarian Indian caste lifestyles and identities among Peru's peasant communities, which showed up numerically as Indianisation in the century's rudimentary census documents. Much of the new historical literature surveyed before, as well as a closer recent study by Adrian Pearce, supports this picture. ${ }^{29}$ Peru's rural world was thus unlike Mexico's, where inter-elite struggles and the new and unstable republican state (probably due to its geographic predominance) intruded more on the daily lives of peasants, who were becoming visibly more mestizo in the post-colonial era. Mexican peasants countered, according to John Tutino's systematic historical interpretation, with an ever-growing state of insurrection, whereas in Peru there were only sporadic and scattered peasant uprisings in the nineteenth century and no campesino revolution in the twentieth. ${ }^{30}$ One might continue this comparison by noting the dramatic and timely appearance in Mexico of a durable developmental elite dictatorship, the Porfiriato, which in whatever complicated fashion, and whatever complex relation to rural folk, ended in a social revolution joined by many aroused mestizo-ised peasants.

In the selva, Peru's third and most disarticulated imagined national space, the European presence and state visibly retreated through much of the nineteenth century, its borders eroded by indigenous Amazonian attacks (by so-called barbarous Chunchos) and their geographic frontier advances. Only in recent decades, first after the militarisation of the explosive illicit cocaine trade of the Huallaga region and most recently with state-indigenous resource

29 Paul Gootenberg, 'Population and Ethnicity in Early Republican Peru: Some Revisions', Latin American Research Review, 26: 3 (1991), pp. 109-57; Adrian J. Pearce, 'Reindigenisation and Native Languages in Peru's Long Nineteenth Century (1795-1940)', in Adrian Pearce and Paul Heggarty (eds.), History and Language in the Andes (London: Palgrave MacMillan, 201 I ), pp. I35-63; Mark Thurner, From Two Republics to One Divided. There are now fine local studies of haciendas and communities, such as Nils Jacobsen, Mirages of Transition: The Peruvian Altiplano, 1780-1930 (Berkeley, CA: University of California Press, I 993); and Lewis Taylor, 'Estates, Freeholders and Peasant Communities in Cajamarca, I 876-1972', Centre of Latin American Studies Working Paper no. 42 (Cambridge: University of Cambridge, 1986); and 'Indigenous Peasant Rebellions in Peru during the I 880 o', in Kevin Gosner and Arij Ouweneel (eds.), Indigenous Revolts in Chiapas and the Andean Highlands (Amsterdam: CEDLA, 1996), pp. 183-216.

30 John Tutino, From Insurrection to Revolution in Mexico: Social Bases of Agrarian Violence (Princeton, NJ: Princeton University Press, 1986); see also a recent speculative essay of Augosto Ruiz Zevallos, 'Mobilización sin revolución: el Perú en tiempos de la Revolución Mexicana', Documento de Trabajo no. 167 (Lima: Instituto de Estudios Peruanos, 201 I). The mass Andean peasant hacienda takeovers of the early 1960 s might be seen as the much delayed social response. 


\section{I36 Paul Gootenberg}

conflicts which have mobilised communities, has this huge ecological swathe of eastern Peru truly come under tangible governmental purvey. ${ }^{3}$

So most Peruvians, subalterns likely more than would-be elites, probably ignored or evaded the existence of a national state and authority - falling into, or building, for better or worse, a James Scott-like state of benign 'anarchy' instead. ${ }^{32}$ By no means was it an egalitarian anarchy: the uneven resources and influence of Peruvians contributed to the lack of effective state ties or to associative or organisational discipline. The disarticulation of Peruvian people(s) from the state likely lurched along in phases, correlating with the state's visible shrinkage and expansion generated around Lima, and around export revenue cycles and meandering caudillo campaigns. Many literate town and city notables probably wanted a stronger, wider, more mobilising national state $-\mathrm{a}$ few, with regional affiliations, perhaps through imagined liberal institutions and values - but the other two million or so other Peruvians likely did not worry or think about it much. From a sociological perspective, Peru's nineteenth-century state had little working 'symbolic capital' (Pierre Bourdieu's term) or working bundles of 'social power' (Michael Mann's). None of this is to say that the peasants and other peoples of Peru were ignorant or Hobsbawmian 'pre-politicals'; rather, it contests a statist teleological lens - a statolotry - that reads backwards their questionable state capture or allegiances.

This speculative digression, about whether legitimating or socialisingdisciplining ties might be a missing link in thinking about liberalism, the state or developmental possibilisms, is not meant to deny other, longer developments. Clearly - and this also needs to be researched explicitly over the long term - even weak states like Peru's were slowly setting territorial, discursive, administrative and infrastructural roots in the Andes, attracting a limited (often squabbling) citizenry base. After all, even a relatively poor and unstable state like Peru was a legacy of the Iberian 'West', with its governing plazas de armas of town architecture and institutions, religious disciplining, elaborate legal codes, and a socialised peasantry long formed under Spanish colonialism. These foundations were buttressed during the later nineteenth century with French-style administrative and knowledge models and during the twentieth by templates, advice and finance filtering mainly from the

${ }^{31}$ Paul Gootenberg, Andean Cocaine: The Making of a Global Drug (Chapel Hill, NC: University of North Carolina Press, 2009), chap. 5; Pilar García Jordán (ed.), Fronteras, colonización, y mano de obra indigena en la Amazonía andina (siglos XIX-XX) (Lima: Pontificia Univeridad Católica del Perú and Universitat de Barcelona, I998); Nuria Sala I Vila, Selva y Andes: Ayacucho (1780-1929). Historia de una región en la encrucijada (Madrid: Consejo Superior de Investigaciones Científicas, 2001).

${ }^{32}$ James C. Scott, The Art of Not Being Governed: An Anarchist History of Southeast Asia (New Haven, CT: Yale University Press, 2009). 
United States. During and after Leguía's oncenio regime of the I920s, the state expanded more intensively and rapidly through national road-building, labour drafts, public health projects, higher literacy and education rates, new mass media, factories, mines, food commissaries and a growing state bureaucracy, creating more modern subjects and inclusive hierarchies. ${ }^{33}$ Over the long term a 'nation' and national culture congealed, with effective symbols, sovereignties and subjectivities, as well as many Peruvian citizens, though riven by steep inequalities and contesting interpretations of those symbols and powers. By the early twentieth century most of Peru's social movements were recognisably 'modern', if not necessarily liberal, though the shocking anti-state terror and official violence associated with the difficult repression of the Sendero Luminoso insurrection during the 1980 os later put many of these assertions into doubt. What is harder to buy is that this long-term emergence of the Peruvian (or, for that matter, Latin American) nation-state came to or from a one-way threshold where liberalism, the state and development reached some stable 'take-off' point or stage - a precursor prerequisite mythology of $1960 \mathrm{~s}$ 'modernisation' theory and its recent echo, liberal neo-institutionalism. ${ }^{34}$

Wherever this vibrant, growing and still disparate Peruvian historiography takes us, I hope it can link again to big and complicating questions about liberalism and the state. As noted by Alan Knight, the generational split between the historians of the I970s (with their focus on development) and those of the I990s (who focused on politics), besides reflecting their different training, mindsets or political contexts, also embodies a historical dichotomy that has typified Latin America since the nineteenth century: the divorce of nineteenth-century 'economic liberalism' (free trade, commodification, property rights, market individualism) from classical eighteenth-century political liberty, equality and constitutional liberalism.35 This kind of split - intellectual yearnings and ideologies of liberalism's natural convergence aside - is actually not anomalous in a global historical sense, for there is little intrinsic to markets or commerce that dictates stronger democracy, political or

${ }^{3}$ Drinot, The Allure of Labor; Christina Ewig, 'Health Policies and the Historical Reproduction of Class, Race, and Gender Inequality in Peru', in Paul Gootenberg and Luis Reygadas (eds.), Indelible Inequalities in Latin America (Durham, NC, and London: Duke University Press, 2010), pp. 53-80; David Nugent, Modernity at the Edge of Empire: State, Individual, and Nation in the Northern Peruvian Andes, I885-1935 (Stanford, CA: Stanford University Press, 1997).

${ }^{34}$ For a trenchant critique, see Adam Przeworski, 'The Last Instance: Are Institutions the Primary Cause of Economic Development?', European Journal of Sociology, 65: 2 (2004), pp. $165-88$.

35 Alan Knight, comments at symposium, 'Paper Leviathans: State-Building in Latin America and Spain', Princeton University, 2009. This is not to overlook the long-running debate around this question: see Albert O. Hirschman, The Passions and the Interests: Political Arguments for Capitalism before Its Triumph (Princeton, NJ: Princeton University Press, 1977). 


\section{38 Paul Gootenberg}

human rights, and equality. Indeed, if Latin America is known for anything on the global stage of liberalism, it is for the 'authoritarian liberalism' expertly practiced by the export-oriented developmental regimes of 'order and progress' of the late nineteenth century, from Porfirio Díaz in Mexico to the Brazilian Republic and the sundry aristocratic and oligarchic republics of South America. ${ }^{36}$ Export liberalism has been linked to the top-down expansion of state power and a hardening of long-term social inequalities, exclusion and dualism.

Nor is this equation dead. At least two recent Peruvian regimes, Alberto Fujimori's in the r990s and Alan García's domesticated and assimilated twenty-first-century Alianza Popular Revolucionaria Americana (American Popular Revolutionary Alliance, APRA) - born of course as an anti-oligarchic 'revolutionary' party - embraced the national tradition that divorces growthinducing liberalisation from political democratisation and equalising social policies. 37 Decades ago, during the heyday of Latin American structuralism, Rosemary Thorp characterised the recurrent modern policy motif of Peru as an 'open economy' orthodoxy, and that diagnosis still seems to fit, making liberal Peru once again an outlier in a more left-leaning heterodox Latin America, now led by burgeoning developmental social democracies like Brazil's. The unusual appeal, staying power and exclusionary terms of Peru's neoliberalism demand more scrutiny. For a remarkable example, the current Peruvian government of Ollanta Humala (at the time of writing in mid-20 I2), which initially frightened many observers at home and abroad with its incoming Velasquista-style campaign rhetoric in $20 \mathrm{I}$, has already effectively returned to the pragmatic Fujimori-García political and policy style, albeit with more lip service paid to equality issues. Since 1990 every Peruvian regime seems to ride in on the 'Left' only to rule on the side of the Right and in tandem with the global market. The decades-long political vigour of Peru's exclusionary liberalism comes, I venture, from the memory-politicking of a national security state that evokes the ghosts of a failed leftist insurgency (Sendero Luminoso) and that still pins virtually all of Peru's problems on the fleeting statist reforms (nationalisations, agrarian reform, lofty oversized development projects, and bureaucratic state expansion) of the Velasco era in the late 1960 s. It is also powerfully fuelled by incredible enclave and extractive

${ }^{36}$ See Love and Jacobsen (eds.) The Visible Hand; Vincent C. Peloso and Barbara A. Tenenbaum (eds.), Liberals, Politics and Power: State Formation in Nineteenth-Century Latin America (Athens, GA, and London: University of Georgia Press, 1996); or even Paul Gootenberg, 'The Social Origins of Protectionism and Free Trade in NineteenthCentury Lima', Journal of Latin America Studies, 1 4: 2 (1982), pp. 329-58.

37 Rosemary Thorp and Geoffrey Bertram, Peru, 1890-1977: Growth and Policy in an Open Economy (London: MacMillan, 1978); Paulo Drinot, 'The Meaning of Alan García: Sovereignty and Governmentality in Neoliberal Peru', Journal of Latin American Cultural Studies, 20: 2 (201 I), pp. 179-95. 
exports, such as high-technology gold and copper mining. Peru is now growing impressively, but the intellectual class still worries aloud whether this twentyfirst-century boom is a rerun of the nineteenth-century prosperidad falaz ('false prosperity', Basadre's evocative term for the catastrophic illusions of the guano and nitrate export age).

Across Latin America, one of the core insights of the structuralist and dependency schools is currently enjoying an intellectual rehabilitation of sorts: the idea that global capitalist integration and liberal institutional reforms in the nineteenth century (and during other processes and epochs of Latin American history) actually exacerbated political inequalities and social exclusions across the region, even when open markets brought about needed productivity gains, state stabilisation and significant infrastructural investment. ${ }^{38}$ There has been dependency and development and inequality, in a new variation on Fernando Henrique Cardoso's sophisticated structuralist dependency thought. Indeed, Cardoso, during his influential presidency of Brazil (1995-2003), refocused his own vision: Brazil was no longer, he announced, an 'underdeveloped' nation but an 'unjust' nation, suffering from staggering class, regional and racial inequalities - a suggestive categorisation for a number of growing Latin American countries, though one that also inadvertently lets development off the hook for its production and reproduction of social inequalities. Over the long haul Latin America has seen citizen-, civil society- and nation-building, along with often long bouts of repression and seemingly ancient and intractable social exclusions. ${ }^{39}$ No doubt the issue of social inequality within the liberal-capitalist growth style was handled too deterministically by its critics in the past, but historians or social scientists who insist on thinking narrowly about the 'economic' or 'political' (much less cultural) side of liberalism will continue to reproduce this dichotomy economics/politics - rather than engaging their multiple divergences, linkages or historical contingencies. These political economy lenses are essential for grasping the region's durable or indelible inequalities, which lie at the heart of

${ }^{38}$ John H. Coatsworth, 'Inequality, Institutions, and Economic Growth in Latin America', Journal of Latin American Studies, 40: 3 (2008), pp. 545-69; Ricardo D. Salvatore, John H. Coatsworth and Amílcar E. Challú (eds.), Living Standards in Latin American History: Height, Welfare, and Development, I750-2000 (Cambridge, MA: David Rockefeller Center for Latin American Studies, Harvard University, 2010).

39 Fernando Henrique Cardoso and Enzo Faletto, Dependence and Development in Latin America (Berkeley, CA: University of California Press, 1979); Gootenberg and Reygadas (eds.), Indelible Inequalities in Latin America; Rosemary Thorp and Maritza Paredes, La etnicidad y la persistencia de la desigualdad: el caso peruano (Lima: Instituto de Estudios Peruanos, 20II); Paulo Drinot, 'Institutional Development in Peru in Historical Perspective', in John Crabtree (ed.), Making Institutions Work in Peru: Democracy, Development, and Inequality Since 198I (London: Institute for the Study of the Americas, 2006), pp. 5-23. 
continuing widespread scepticism about the fit of liberalism to Latin American societies.

\section{Back to the Present?}

I have yet to reconcile these two historical waves about the Peruvian state: the first, concerned with analysis, however forced, of the state's role or lack thereof in structuring and fostering economic development, and the second, with the complex ingredients of post-colonial political life. This essay has at least shown some ways in which changing historical production has grappled with specific fields of contemporary Latin American political economy. I have suggested that the newer historical literature, even if eliding the powers of material and market forces, lends us better clues than past deductive or imaginary class or dependency analysis for grasping the workings of republican states like Peru's. The refurbished appeal of Weberian ideas about the embeddedness of economies in political institutions and culture (and the return to a critical sociology about divergent and multiple modernities), and of the institutional nexus between economics and power, would seem to open a working space for bringing such big concerns back together. Historical sociologists have begun dissecting the 'disciplinary' micro-foundations of diverse economic growth experiences, opening a neo-Weberian or Eliasian space even to historians infatuated with Foucauldian notions of the state. ${ }^{40}$ The explicit and growing study of Latin American inequalities is another way to bring the developmental and the political back into an active and urgent dialogue.

Historical social scientists, if indirectly, are also beholden to the possibilities of the present, and the role of the state in economic development is suddenly timely again. The eclipse of late twentieth-century liberal market fundamentalism, by gradual political reconquest in Latin America and by the sudden 2008 market implosion in the 'Washington Consensus' metropole, is ushering in a significant period of political and economic experimentation throughout most (although not all) of the Americas. Yet today, in contrast to the r 9605 and I970s, even the most active unorthodox attempts at social reform, national development and neo-populism (from Brazil, Bolivia and Venezuela to the campaign politics of Humala in Peru) tolerate or encourage both a range of liberal rights and market-generated employment. In this leftwards shift, as noted, Peru has remained one of the steadfast neoliberal outliers, but

${ }^{40}$ Julia Adams, Elizabeth Clemens and Anna S. Orloff (eds.), Remaking Modernity: Politics, History, and Sociology (Durham, NC, and London: Duke University Press, 2005); Peter Evans, Embedded Autonomy: States and Industrial Transformation (Princeton, NJ: Princeton University Press, 1995); Michael Mann, The Sources of Social Power, vol. I (Cambridge: Cambridge University Press, 1986); William H. Sewell, Logics of History: Social History and Social Transformation (Chicago, IL: University of Chicago Press, 2005). 
paradoxically this accentuates the Andean country's long role as a laboratory for ideas about liberalism and the state. The hybrid forms of the emerging Latin American Left, and the swelling demand for both development and equality, will no doubt inspire rethinking of comparable dilemmas in the past. Like the cultural recognition of multiple modernities, and the sociological grasp of many pathways to modernisation, there are again suddenly 'many recipes' for economic growth - a realisation that also helps us to reimagine a more diverse, possibility-laden past. $^{4 \mathrm{I}}$

\section{Spanish and Portuguese abstracts}

Spanish abstract. Este ensayo examina las concepciones cambiantes del Estado y el desarrollo dentro de los recientes materiales de la historiografía peruana. Las amplias interpretaciones de una dependencia estructural de los años 70 y 80 dieron paso a un 'giro político' más difuso y creativo durante los años 90 y después. Estas cambiantes ideas históricas, que todavía no se logran sintetizar del todo, se relacionan con diferentes concepciones globales y fases de liberalismo económico; el cambiante papel que se percibe de los Estados sobre el desarrollo; y la integración y disciplinamiento social de una nación peruana enormemente desigual. Algunos aspectos de estos debates históricos peruanos pueden ayudar a esclarecer controversias similares en gran parte de la región.

Spanish keywords: Perú, historiografía, siglo XIX, liberalismo, desarrollo, el Estado

Portuguese abstract. Este ensaio examina as mudanças de concepção de estado e desenvolvimento através dos recentes movimentos na historiografia peruana. As amplas interpretações estruturalistas/dependentistas dos anos setenta e oitenta deram lugar à uma 'tendência política' mais difusa e criativa sobre a 'transformação política' durante e após os anos noventa. Essas idéias históricas mutantes, que ainda resistem à síntese, se referem à conceitos globais distintos, assim como à fases de liberalismo econômico, à evolução da percepção do papel dos estados no desenvolvimento e à integração e ao disciplinamento social de uma nação peruana com vastas desigualdades. Aspectos destes debates sobre a historiografia peruana poderão esclarecer controvérsias similares presentes na região.

Portuguese keywords: Peru, historiografia, século XIX, liberalismo, desenvolvimento, o estado

${ }^{41}$ Paraphrasing Dani Rodrik, One Economics, Many Recipes: Globalisation, Institutions, and Economic Growth (Princeton, NJ: Princeton University Press, 2007); Carlos Iván Degregori (ed.), No hay país más diversa: compendio de antropología peruana (Lima: Red para el Desarrollo de las Ciencias Sociales en el Perú, 2000). 